\title{
FIT FOR EDUCATIONAL PURPOSE?
}

\section{THE FINDINGS OF A MIXED METHODS STUDY OF NURSES' DECISIONS TO PARTICIPATE IN PROFESSIONAL DEVELOPMENT AND RECOGNITION PROGRAMMES}

\author{
Samantha Heath, Sally Clendon, and Roberta Hunter
}

\section{INTRODUCTION}

Precursors to Professional Development and Recognition Programmes (PDRPs) emerged in the United States during the 1980s and, over the past three decades, have become well known and used in New Zealand. Pedagogically, PDRPs are often underpinned by the seminal work of Benner (1984) which supports nurses to develop critical and clinical thinking and importantly, expertise. As a tool supporting Continuing Professional Development (CPD), a PDRP has additional benefits. These include validation of regulatory continuing competence requirements and, at some levels, a financial reward. Yet, when given the option to participate in a PDRP, nurses choose not to. This article reports on findings from a recently completed, mixed methods study where nurses' decisions to participate in a PDRP were examined. Their explanations portrayed how they were positively disposed to the programme but that time, confusion between regulatory competencies, and PDRP requirements, together with the responses of their colleagues, often made crossing the divide between simply liking the idea of PDRPs and submitting a portfolio impossible. Given this context, are PDRPs still fit for purpose?

\section{BACKGROUND}

PDRPs grew from the need to document the contribution of nursing during significant change in the New Zealand health system (Peach, 2013). Portfolio development presented a way of increasing the visibility of nurses' contributions to healthcare. The concept grew, and the first PDRPs emerged, mirroring advances in the USA where ladder systems supported professional development. Ongoing refinement was tailored to include the needs of multiple stakeholders. Each programme had a local flavour with discrete submission requirements, and some organisations made PDRPs compulsory. In subsequent decades, PDRPs have continued to mature, and programme numbers have steadily increased (Nursing Council of New Zealand, 2016). Present-day descriptions of the outcomes of PDRPs now articulate their role in the advancement of nurses' professional development and in supporting the demonstration of competencies required by their regulator (Canterbury District Health Board, 2020). 


\section{PEDAGOGY}

Arguably, the most important stakeholder in a PDRP is the patient. Patients should have reasonable expectations that they will be attended by a practitioner who can provide high-quality care with the best health outcomes. Furthermore, evidence exists to support the view that when care is provided by nurses who are expert practitioners, detection of deterioration is enhanced, there is timely mobilisation of healthcare resources and improved clinical decision-making (Manley, Hardy, Tichen, Garbett \& McCormack, 2005; Minick \& Harvey, 2003; Morrison \& Symes, 20II). It might be important then to find that modern CPD programmes were based on contemporary pedagogies that promoted acquisition of expertise. Championing this space, a PDRP sits as an example of the use of Benner's (1984) 'Novice to Expert' theory to underpin the learning outcomes of CPD, and reflects a pedagogy that principally values the development of expert practitioners. It is purported to do so by encouraging the use of educational strategies like reflection to facilitate nurses' professional growth (Benner, 1984).

When used effectively, reflection encourages nurses to 'see' their clinical practice through the task of writing practice exemplars. Indeed, beyond the initial level, a PDRP portfolio contains just this type of evidence. Subsequent assessment is based on evidence of professional behaviours consistent with Benner's (1984) 'Novice to Expert' practitioner characteristics. Successful assessment enables progression, and achievement of the highest levels is financially rewarded. Portfolios are valid for three years after which they are re-presented with new exemplars demonstrating continued professional development.

\section{STAKEHOLDER PERSPECTIVES}

PDRP stakeholders include the Nursing Council of New Zealand (NCNZ). Their formal approval of a PDRP delegates responsibility for assessment of continuing competence requirements to local assessors. For NCNZ, approval reduces the significant workload of validating continuing competence required as part of the Health Practitioners Competence Assurance Act 2003. In exchange, nurses who participate are excluded from NCNZ's random recertification audit process. For employers, there comes an assurance that nurses have met their regulatory requirements. Furthermore, as a tailor-made career framework, an approved PDRP has quantifiable financial risk implications, and the 'approved status' might signal a level of organisational commitment to nurses' professional development.

Alignment of PDRP requirements has been the concern of the National Evidential Working Group who first met in 2005. This group has provided clarity about PDRPs as a legitimate CPD activity and has actively promoted its recommendations for PDRP evidential requirements. The most recent version of these was endorsed by the Nurse Executives of New Zealand (2017); (Evidential Requirements Working Party, 2009). With publication, came the clear directive that there should be national consistency across all programme providers within five years.

Continued work, started by the New Zealand Nurses' Organisation (formerly New Zealand Nurses' Association), demonstrated the benefits associated with using remuneration packages and frameworks like PDRPs (Buchan \& Thompson, 1997). Allowances are now included in the Multi-Employer Contractual Agreement (MECA). More recently, two days of paid study leave have been included for the preparation or maintenance of a PDRP portfolio in order to encourage nurses to participate.

Unmistakably, there have been extensive efforts to support contemporary PDRPs for nurses. It might be supposed that nurses would participate in large numbers, given the array of available benefits. Yet, if engagement rates collated by the National PDRP Co-ordinators group $(2014,2015,2016)$ were considered as proxy for nurses' voice on their eagerness for uptake, a PDRP might not be the framework of choice. In organisations where a PDRP is compulsory, participation rates are above 80 percent while in those where it is voluntary, rates are below 20 percent (National PDRP Co-ordinators 2014, 2015, 2016). If the PDRP truly is fit for future purpose, then there must be greater understanding of voluntarism in nurses' decisions to participate in a PDRP. 


\section{ENGAGEMENT WITH CPD: THE CHAIN OF RESPONSE MODEL}

Cross (1981) favours the view that a myriad of factors affects a decision to participate in any adult learning. Visualised in the 'Chain of Response Model' a dynamic interaction between the factors, each factor impacting an eventual decision to participate is indicated (see Figure I). The factors are entirely learner focussed and, as such, penetrate the temptation to assume that the benefits provided by well-constructed pedagogy, regulatory compliance or financial reward are sufficient to ensure participation. Undoubtedly, the model could be used to examine nurses' PDRP participation. Used as the conceptual framework, the Chain of Response Model (Cross, 198I) provided structure across all phases of the work.

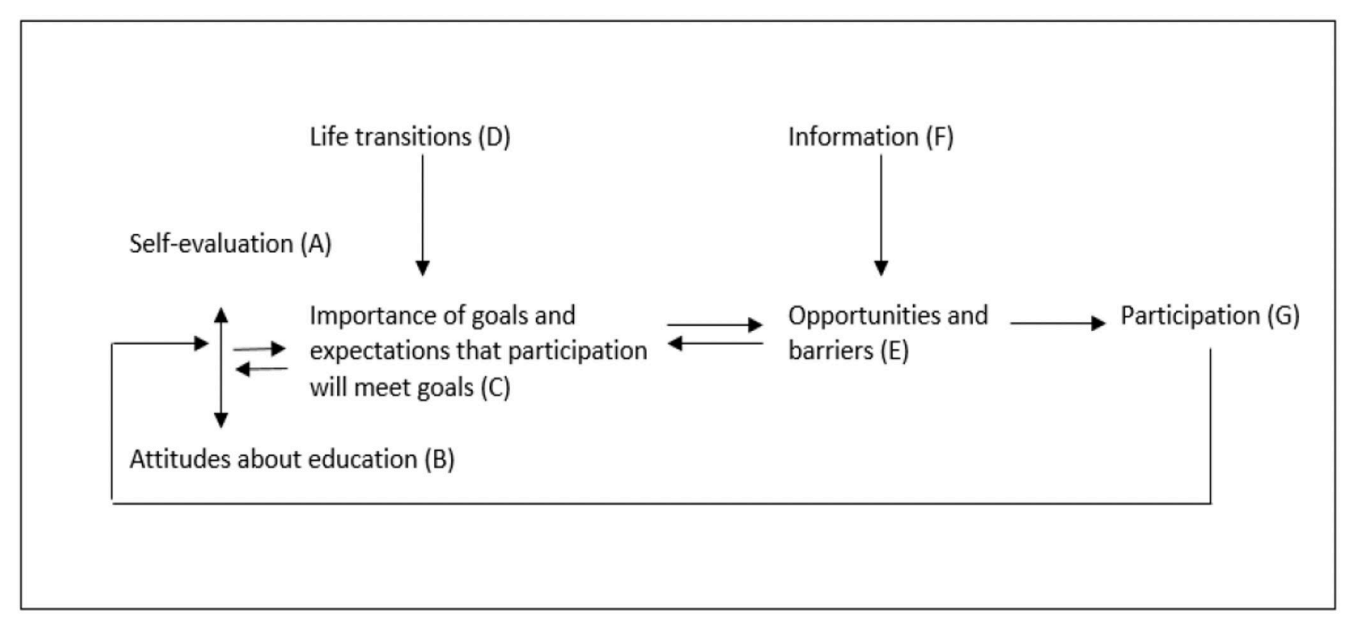

Figure I. Chain of Response Model Source: Cross (1981).

\section{ETHICAL CONSIDERATIONS}

Massey University Human Ethics Committee (MUHEC) approval was granted in March 2016. As part of the ethics approval process, the Senior Leadership Team and Māori Advisory Group at the organisation were invited to review the study proposal and consider providing their support. Access to relevant nursing staff and use of organisational resources was formally granted in conjunction with MUHEC approval.

\section{METHOD}

The research was conducted in a specialised health support service Crown entity where nurses had access to a voluntary PDRP approved three years previously by NCNZ. Financial rewards were available for completion of the two highest levels; the organisation was invested in nurses' CPD and yet, participation mirrored national rates of less than 20 percent. Teddlie and Tashakkori (2009) and Robson and McCartan (2016) independently suggested that indicators like these participation rate discrepancies are justifiable reasons for undertaking research. They further explained that answering questions about practice using research means that answers are more likely to be valued and contribute to improvements in practice. Their approach is one of pragmatism (Teddlie \& Tashakkori, 2009; Robson \& McCartan, 2016).

The adoption of a pragmatic approach and use of an explanatory-sequential mixed methods design created the opportunity to use quantitative and qualitative data to understand nurses' decisions to participate in PDRPs. As with all mixed methods designs, there must be a mixing of the data between each phase of the study (Creswell, 
2009). Postal surveys were used to identify nurses' knowledge and attitudes to PDRPs in Phase I. Data from the surveys were analysed and formed the basis for the questions asked in Phase 2, semi-structured interviews. Here, nurses explained insights from the quantitative data (Phase I). Interpretation through data convergence illustrated the existence of consistencies or contradictions and signposted likely underlying explanations (Moseholm \& Fetters, 2017); (see Figure I).

\section{Phase I: Postal survey}

Postal surveys were distributed to a convenience sample of 129 Registered and Enrolled Nurses employed on the day the survey went live. The choice to use postal surveys allowed for the geographic distribution of potential participants and their sporadic access to digital devices for online completion. Nurses were eligible to participate whether they had completed the organisation PDRP or not, as long as they were not in a 'senior' nursing role.

Survey questions invited a response about knowledge of PDRPs, disposition toward CPD and PDRP activity. Responses to factors identified from the literature as affecting participation in CPD were recorded. Demographic information was obtained. Participants were invited to add free-text responses for any unaddressed areas. There was a 64 percent response rate $(n=82)$ when the survey closed.

\section{Phase 2: Semi structured interviews}

Thirty-six of the survey respondents volunteered to be interviewed: 15 were arranged, 14 were conducted. Interviewing survey respondents enabled the sample to be nested, further strengthening the design through mixing both sample and data between phases. A general inductive approach was taken to analyse the interview transcripts (Braun \& Clarke, 2006).

\section{NURSES' EXPLANATIONS}

No single factor materialised as the chief influence on PDRP participation from the survey data. Instead, knowledge about the relationship between PDRP; regulatory requirements and programme processes were highlighted as being problematic. These issues were followed-up at interview. Some of the most noteworthy findings are presented below.

\section{A: Self-evaluation}

Nurses perceived themselves positively as learners. The quantitative data showed their experience of professional development was such they believed further learning would enhance their clinical skills. Eighty-five percent ( $n=$ 70) agreed/strongly agreed that they were capable of completing a PDRP. Yet the optimism reported in the survey appeared contradictory to interview narratives which identified PDRPs as being daunting for beginners. Further, explanations of of why 'understanding what to write to validate NCNZ competencies' was the fourth greatest factor impacting on completion of a PDRP, illustrated the obstacles nurses encountered during PDRP preparation. Examples of the converged data demonstrate how knowing what was required and the preferred writing style were problematic (see Table I). 


\begin{tabular}{|c|c|c|c|c|}
\hline \multicolumn{5}{|c|}{$\begin{array}{l}\text { Chain of response: A: Self-evaluation } \\
\text { The way in which each learner perceives their own ability to succeed }\end{array}$} \\
\hline $\begin{array}{l}\text { Associated } \\
\text { survey theme }\end{array}$ & $\begin{array}{l}\text { Quantitative } \\
\text { data }\end{array}$ & Qualitative data example & $\begin{array}{l}\text { Associated } \\
\text { interview code }\end{array}$ & $\begin{array}{l}\text { Data } \\
\text { convergence }\end{array}$ \\
\hline $\begin{array}{l}\text { I am capable of } \\
\text { completing a } \\
\text { PDRP portfolio }\end{array}$ & $\begin{array}{l}\text { Agree }(\mathrm{n}= \\
38) \\
\text { Strongly } \\
\text { agree }(\mathrm{n}=32)\end{array}$ & For a beginner, PDRP is daunting & Options work & No \\
\hline $\begin{array}{l}\text { Understanding } \\
\text { what to write to } \\
\text { validate NCNZ } \\
\text { competencies }\end{array}$ & $\begin{array}{l}\text { Ranked } 4 \text { as a } \\
\text { factor } \\
\text { influencing } \\
\text { engagement }\end{array}$ & $\begin{array}{l}\text { Some of them you have to read a couple of times } \\
\text { to try to decipher what they are actually } \\
\text { wanting. A lot of it is to do with that language } \\
\text { thing of how do I answer that? } \\
\text { It is actually quite hard to try and write that stuff down } \\
\text { and so I know that some people are struggling with } \\
\text { that and I think they just give up. }\end{array}$ & $\begin{array}{l}\text { Competency } \\
\text { validation }\end{array}$ & Yes \\
\hline
\end{tabular}

Table I. Self-evaluation.

\section{B: Attitudes about education}

An outcome of previous experience and the impact of significant reference groups, attitudes about education were both cumulative and fragile. Having indicated they were motivated to complete PDRPs in the survey, interviews showed how nurses' efforts could easily be derailed by programme facilitators or peers. Talking about her PDRP experience, one nurse showed how continued requests for revisions from an assessor impacted on her motivation to complete her PDRP (see Table 2). Eventually, she changed her mind about participating. Another nurse indicated how her understanding of the process became confused during meetings with a PDRP leader.

Nurses were also keen observers of those undertaking PDRP. It seemed that those who had not yet started PDRP experienced the process vicariously via their colleagues. Table 2 shows how those who had difficulties preparing their PDRP portfolios could influence the attitudes of others. More troubling though, was the recognition that these narratives came from nurses who had been dissuaded in previous employment. These nurses told how they carried exposure to vicarious experiences with them between jobs. Their vicarious PDRP encounters influenced their decision to participate years later. Fortunately, one beacon of light remained. The PDRP-friendly charge nurse who was an anchor and cheerleader when it mattered most.

Chain of response: B: Attitudes about education

An outcome of previous experience and significant reference groups

\begin{tabular}{|c|c|c|c|c|}
\hline $\begin{array}{l}\text { Associated } \\
\text { survey theme }\end{array}$ & $\begin{array}{l}\text { Quantitative } \\
\text { data }\end{array}$ & Qualitative data example & $\begin{array}{l}\text { Associated } \\
\text { interview code }\end{array}$ & $\begin{array}{l}\text { Data } \\
\text { convergence }\end{array}$ \\
\hline $\begin{array}{l}\text { I am motivated } \\
\text { to complete a } \\
\text { PDRP portfolio }\end{array}$ & $\begin{array}{l}\text { Agree }(\mathrm{n}= \\
35) \\
\text { Strongly } \\
\text { agree }(\mathrm{n}=16)\end{array}$ & $\begin{array}{l}\text { Initially I wanted to do my PDRP for my own self and to } \\
\text { further my own knowledge but it got to a point where } \\
\text { actually no, I didn't want to do it anymore. } \\
\text { Every time I had a meeting with the person who ran the } \\
\text { PDRP, she just got me more and more confused. }\end{array}$ & $\begin{array}{l}\text { Personal } \\
\text { experience of } \\
\text { PDRP } \\
\text { completion }\end{array}$ & No \\
\hline $\begin{array}{l}\text { My peers are } \\
\text { supportive of } \\
\text { me completing } \\
\text { a PDRP } \\
\text { portfolio }\end{array}$ & $\begin{array}{l}\text { Neutral } \\
\text { response } \\
(\mathrm{n}=38)\end{array}$ & $\begin{array}{l}\text { We saw [nurse name] go through the process and she } \\
\text { always put a lot of pressure on herself and was quite } \\
\text { vocal with how difficult it was and I think people hear } \\
\text { that. } \\
\text { Initially seeing what she went through. She actually } \\
\text { submitted her portfolio three times andhad it sent } \\
\text { back. And again, it impacted on me, because ... this } \\
\text { person was an epitome of an expert... }\end{array}$ & $\begin{array}{l}\text { Vicarious } \\
\text { experience }\end{array}$ & No \\
\hline
\end{tabular}




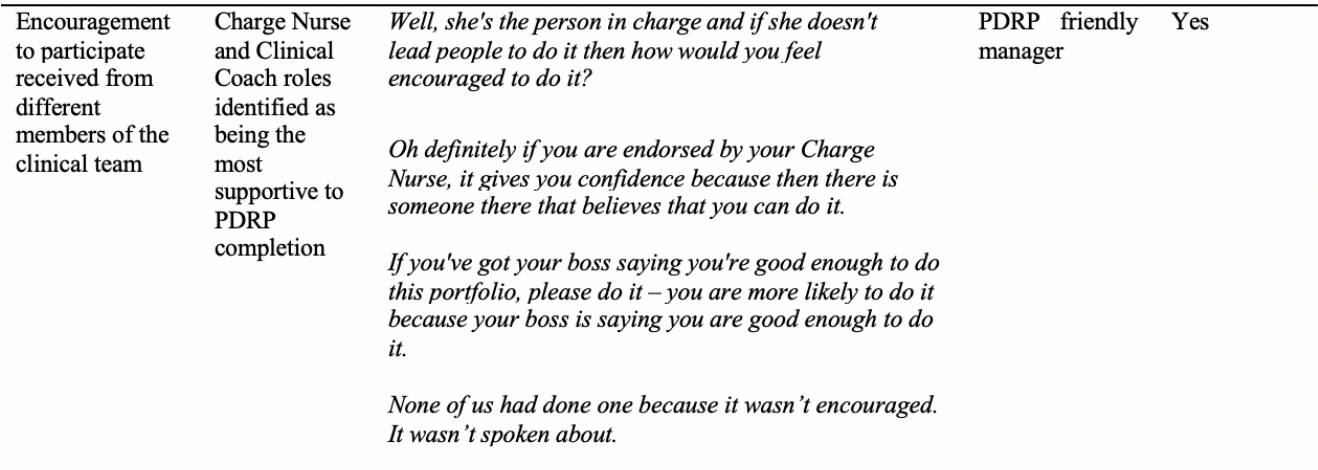

Table 2. Attitudes about education.

\section{C: Importance of goals}

Notwithstanding that the underpinning pedagogy of this, the PDRP used in this study had been carefully crafted, intended learning outcomes that linked case reflections with improved clinical practice were simply not clear to participants. Nurses' goals for PDRPs were not focussed on clinical practice improvement through reflection on action. Yet, if participation was not about improving clinical practice, neither was it about pay allowances. Nurses ranked money tenth in influencing factors; they also argued in favour of professionalism over money as a better driver to participate. It was difficult to decipher nurses' goals of participation. However, when the 'value of the PDRP/continuing regulatory requirements relationship' theme was developed, nurses showed for the first time how PDRP participation avoided regulatory audit (see Table 3).

\begin{tabular}{|c|c|c|c|c|}
\hline \multicolumn{5}{|c|}{$\begin{array}{l}\text { Chain of response: C: Importance of goals and expectations } \\
\text { The expectation that engagement will meet learning needs or aspirations }\end{array}$} \\
\hline $\begin{array}{l}\text { Associated } \\
\text { survev theme }\end{array}$ & $\begin{array}{l}\text { Quantitative } \\
\text { data }\end{array}$ & Qualitative data example & $\begin{array}{l}\text { Associated } \\
\text { interview code }\end{array}$ & $\begin{array}{l}\text { Data } \\
\text { convergence }\end{array}$ \\
\hline $\begin{array}{l}\text { Completing a } \\
\text { PDRP portfolio } \\
\text { helps me to } \\
\text { demonstrate my } \\
\text { clinical } \\
\text { capabilities }\end{array}$ & $\begin{array}{l}\text { Ranked } 7 \text { as a } \\
\text { factor } \\
\text { influencing } \\
\text { engagement }\end{array}$ & I don't believe it makes me a better nurse. & $\begin{array}{l}\text { The value of the } \\
\text { PDRP/Regulatory } \\
\text { requirements } \\
\text { relationship }\end{array}$ & Yes \\
\hline $\begin{array}{l}\text { The allowance } \\
\text { that is available } \\
\text { for completing } \\
\text { some levels of } \\
\text { the PDRP }\end{array}$ & $\begin{array}{l}\text { Ranked } 10 \text { as } \\
\text { a factor } \\
\text { influencing } \\
\text { engagement }\end{array}$ & $\begin{array}{l}\text { It had no bearing on my decision, none whatsoever. } \\
\text { I don't know the numbers but that wouldn't be something } \\
\text { that I actually consider too much. }\end{array}$ & $\begin{array}{l}\text { Money } \\
\text { motivation }\end{array}$ & Yes \\
\hline $\begin{array}{l}\text { Knowledge } \\
\text { about PDRP }\end{array}$ & $\begin{array}{l}\text { Professional } \\
\text { requirements } \\
\text { met by PDRP } \\
(\mathrm{n}=81)\end{array}$ & $\begin{array}{l}\text { To be honest, I did it so that I wouldn't get audited. } \\
\text { Because I don't want to be audited because it's sprung } \\
\text { on me. }\end{array}$ & $\begin{array}{l}\text { The value of the } \\
\text { PDRP/Continuing } \\
\text { requirements } \\
\text { relationship }\end{array}$ & No \\
\hline
\end{tabular}

Table 3. Importance of goals and expectations. 


\section{D: Life transitions}

Older nurses considered that PDRP was no longer useful, suggesting a need to consider other ways to meet their CPD requirements (see Table 4). However, they saw disadvantage in not being excused from recertification audit but provided the following insight:

Other factors such as attending training sessions, lectures and participating in perfecting the actual tasks at hand are more beneficial (Respondent 43).

\begin{tabular}{lllll}
\hline $\begin{array}{l}\text { Chain of response: D: Life transitions } \\
\text { Concerns learners } \text { at different stages of their life cycle }\end{array}$ & \\
\hline $\begin{array}{l}\text { Associated } \\
\text { survev theme }\end{array}$ & $\begin{array}{l}\text { Quantitative } \\
\text { data }\end{array}$ & Qualitative data example & $\begin{array}{l}\text { Associated } \\
\text { interview code }\end{array}$ & $\begin{array}{l}\text { Data } \\
\text { convergence }\end{array}$ \\
\hline Age & $\begin{array}{l}\text { Additional } \\
\text { qualitative } \\
\text { commentary }\end{array}$ & $\begin{array}{l}\text { Ifound it so hard to complete and I am so close to } \\
\text { retirement now I'm not going to bother. }\end{array}$ & Lifespan views & Yes \\
& $\begin{array}{l}\text { Coming to the end of career not planning on } \\
\text { undertaking PDRP. }\end{array}$ & & \\
& & & \\
\end{tabular}

Table 4. Life transitions.

\section{E: Opportunities and barriers}

The top-ranked influence on participation was 'time' and discussion about 'time' began in the free-text responses of the survey. At the interview, the complexity of the issue expanded (see Table 5).

\begin{tabular}{|c|c|c|c|c|}
\hline \multicolumn{5}{|c|}{$\begin{array}{l}\text { Chain of response } \mathbf{E} \text { : Opportunities and barriers } \\
\text { Preparedness to overcome barriers to engage with the learning. }\end{array}$} \\
\hline $\begin{array}{l}\text { Associated } \\
\text { survey theme }\end{array}$ & $\begin{array}{l}\text { Quantitative } \\
\text { data }\end{array}$ & Qualitative data example & $\begin{array}{l}\text { Associated } \\
\text { interview code }\end{array}$ & $\begin{array}{l}\text { Data } \\
\text { convergence }\end{array}$ \\
\hline \multirow[t]{6}{*}{ Time } & $\begin{array}{l}\text { Top-ranked } \\
\text { factor } \\
\text { influencing } \\
\text { CPD } \\
\text { engagement }\end{array}$ & $\begin{array}{l}\text { My lack of computer skills is an influence i.e. Time it } \\
\text { would take me to type for myself. }\end{array}$ & $\begin{array}{l}\text { Time to learn } \\
\text { new skills }\end{array}$ & Yes \\
\hline & & $\begin{array}{l}\text { I think a lot people don't like to have to do things they } \\
\text { consider work-related at home. }\end{array}$ & Personal time & Yes \\
\hline & & So, it would take you more than two days. & Having time & Yes \\
\hline & & $\begin{array}{l}\text { Well not having the time has put me off because I } \\
\text { already know I am quite slow at things anyway. }\end{array}$ & & \\
\hline & & $\begin{array}{l}\text { And you have to accept that you've got to make it } \\
\text { happen. }\end{array}$ & Making time & Yes \\
\hline & & If I wanted to do it, I had to do it outside of work. & & \\
\hline
\end{tabular}

Table 5. Opportunities and barriers.

There was a notion that 'time' was owned. Time could be personal (my time) or work-related (work time). If personal time was involved, the activity was the nurse's responsibility. In contrast, where the activity was undertaken during work time, it was an employer responsibility. However, delineation brought complications especially related to study leave. 
PDRP study leave allocation was a contractual arrangement and inferred employer responsibility. Consequently, it created an expectation a PDRP was completed in the employer's time and was an employment matter. Yet, PDRPs also contained continuing competence requirements for which the employer is not responsible. The result was confusion and respondents were unable to separate regulatory competencies from job-specific ones.

Narratives also connected time with novel perspectives of PDRPs. The development of additional skills, before preparation for a PDRP could begin, took time. Skills included writing self or peer assessments for NCNZ or learning word-processing skills. For nurses who had completed a PDRP, an unforeseen consequence came from colleagues who expected assistance with peer assessment. This consequence was not welcomed because of the time involved.

\section{F: Information}

Cross (198I) indicated that information is the educational 'broker' for recruitment to learning opportunities. She further outlined how failure to provide sufficient information resulted in lost learning even in the presence of other motivating factors. In this study, nurses found themselves fielding inaccurate information about PDRPs from their peers and had to distinguish the correct information before they could begin (see Table 6).

\begin{tabular}{|c|c|c|c|c|}
\hline \multicolumn{5}{|c|}{$\begin{array}{l}\text { Chain of response } \mathbf{F} \text { : Information } \\
\text { The broker for recruitment to learning }\end{array}$} \\
\hline $\begin{array}{l}\text { Associated } \\
\text { survey theme }\end{array}$ & $\begin{array}{l}\text { Quantitative } \\
\text { data }\end{array}$ & Qualitative data example & $\begin{array}{l}\text { Associated } \\
\text { interview code }\end{array}$ & $\begin{array}{l}\text { Data } \\
\text { convergence }\end{array}$ \\
\hline \multirow{2}{*}{$\begin{array}{l}\text { Information } \\
\text { about getting } \\
\text { started on the } \\
\text { PDRP is } \\
\text { readily } \\
\text { available to me }\end{array}$} & $\begin{array}{l}\text { Agree }(n=48) \\
\text { Strongly agree } \\
(n=14)\end{array}$ & $\begin{array}{l}\text {...everyone talks about the PDRP and those people say, } \\
\text { oh gosh - it takes so long. Oh, you've got to do this. } \\
\text { Gossip. Second-hand information. Even before you get } \\
\text { to even seeing what the PDRP actually is. }\end{array}$ & $\begin{array}{l}\text { Second-hand } \\
\text { talk }\end{array}$ & No \\
\hline & & $\begin{array}{l}\text { My only advice to anyone doing PDRP is don't listen to } \\
\text { anyone else and do what suits you. }\end{array}$ & $\begin{array}{l}\text { Overcoming } \\
\text { hidden hurdles }\end{array}$ & No \\
\hline $\begin{array}{l}\text { Resources that } \\
\text { help me to } \\
\text { complete a } \\
\text { PDRP } \\
\text { portfolio are } \\
\text { available to me }\end{array}$ & $\begin{array}{l}\text { Agree }(n=42) \\
\text { Strongly agree } \\
(n=13)\end{array}$ & $\begin{array}{l}\text { It's all online, so it can be accessed easily. } \\
\text { Ifound all the e-learn, the apps and that - I thought } \\
\text { they were really good. }\end{array}$ & $\begin{array}{l}\text { E-learning } \\
\text { support }\end{array}$ & Yes \\
\hline
\end{tabular}

Table 6. Information.

\section{CONCLUSION}

This research provides an opportunity to advance nurses' understanding about the purpose of PDRPs as a CPD framework. While there are benefits of completion in relation to recertification requirements, pedagogically these are not the focus of PDRP. Rather, the primary educational purpose is to develop expert practitioners. Clearly, these learning intentions are overshadowed by the more pressing need of the nursing community to avoid regulatory recertification audits. Consequently, PDRPs have yet to recoup the benefits identified by research like that of Benner (1984), Benner and Tanner (1987) and Manley et al. (2005), who showed the positive impact of expert nurses. Ironically, it is a consequence of embedding regulatory requirements within a voluntary programme that has obscured intended educational outcomes. In the absence of clarity, nurses have made the system work by linking PDRPs and NCNZ requirements to avoid audit rather than develop their nursing practice.

This study also uncovered the close attention nurses pay to the behaviour of others completing PDRPs. Crucially, these findings demonstrated how the PDRP process is role-modelled by participants and sets the tone for a 
culture of completion. Any previous vicarious participation experience also strongly influences decision-making in the present. Although not always the most accurate or inspiring, these messages are some of the most powerful, even when a PDRP-friendly manager supports participation. This finding indicates the need for programme administrators to co-create a positive learning experience that adds value to nursing practice. It is essential to do so because the consequences of a poor experience endure between jobs and across careers.

Certainly, there are challenges in developing post-registration education that is sufficiently appealing. PDRPs could yet be that framework; the problems with it as a CPD framework are not insurmountable. However, to realise the practical benefits and to impact patient care, the competing perspectives of stakeholders need to be realigned. It is insufficient that a programme to support nurses' professional development is not seen to focus on their ability to improve patient outcomes rather, it highlights regulatory compliance and financial reward. There are other avenues through which continuing competence can be regulated and financial reward attributed to expert practice. In times where health dollars are scarce and health indices are by no means equitable, that PDRPs are fit for their educational purpose over any other purpose is an imperative.

Dr. Samantha Heath (100000-000 I-5877-7I28) is currently a Lecturer in Nursing at Unitec. She teaches human biology and evidence for nursing practice on the undergraduate Bachelor of Nursing programme. Samantha has held a variety of teaching positions in academic and clinical settings in New Zealand and the United Kingdom. She has worked across the public and private clinical sectors and has successfully developed and implemented three PDRP programmes. Samantha completed a Doctor of Education degree at Massey University in 2019 in which she examined nurses' decisions to participate in PDRP programmes.

Dr. Sally Clendon (10000-0002-1238-596X) teaches on both Undergraduate and Postgraduate Programmes in Speech and Language Therapy at Massey University. Sally is passionate about access to the curriculum and to literacy learning for children with complex communication needs who use augmentative and alternative communication (AAC). Sally delivers workshops nationally and internationally with a focus on empowering communication partners to create optimal language and learning environments. Her focus is on augmentative and alternative communication (AAC). Sally is an Associate Editor for the AAC journal.

Correspondence to: Dr. Samantha Heath, Unitec Institute of Technology, Private Bag 92025, Victoria Street West, Auckland II42, New Zealand. Email: sheath@unitec.ac.nz 


\section{REFERENCES}

Benner, P. (1984). From novice to expert: Excellence and power in clinical nursing practice. Menlo Park, CA: Addison-Wesley.

Braun, V., \& Clarke, V. (2006). Using thematic analysis in psychology. Qualitative Research in Psychology, 3(2), 77-I01. https://doi. org/10.1191/1478088706qp063oa

Canterbury District Health Board. (2020). Overview of the PDRP. Retrieved from http://edu.cdhb.health.nz/Hospitals-Services/ Health-Professionals/pdrp/Overview-pdrp/Pages/default.aspx

Creswell, J. W. (2009). Research design: Qualitative, quantitative and mixed methods approaches (3rd ed.). London: Sage.

Cross, P. (198I). Adults as learners. San Francisco, CA: Jossey-Bass.

Evidential Requirements Working Party. (2009). Professional development and recognition programme (PDRP): Evidential Requirements Working Party Report. Wellington, New Zealand: Nurse Executives of New Zealand Inc., New Zealand Nurses Organisation.

Manley, K., Hardy, S., Tichen, A., Garbett, R., \& McCormack, B. (2005). Changing patients' worlds through nursing practice expertise: Exploring nursing practice expertise through emancipatory action research and fourth generation evaluation. London: Royal College of Nursing.

Minick, P., \& Harvey, S. (2003). The early recognition of patient problems among medical-surgical nurses. MEDSURG Nursing, 12(5), 29|-297.

Moseholm, E., \& Fetters, M. D. (2017). Conceptual models to guide integration during analysis in convergent mixed methods studies. Methodological Innovations, 10(2), I-II https://doi.org//0.1 I77/2059799|177031/8

Morrison, S. M., \& Symes, L. (20I I). An integrative review of expert nursing practice. Journal of Nursing Scholarship, 43(2), I63- I70. https://doi.org/l0.1111/j.1547-5069.2011.01398.x

National PDRP Co-ordinators. (2014). Minutes of the annual meeting 2014. Auckland: National PDRP Co-ordinators.

National PDRP Co-ordinators. (2015). Minutes of the annual meeting 2015. Auckland National PDRP Co-ordinators.

National PDRP Co-ordinators. (2016). Minutes of the annual meeting 2016. Auckland: National PDRP Co-ordinators.

New Zealand Government. (2003). Health Practitioners Competence Assurance Act. Wellington: New Zealand Government.

Nurse Executives of New Zealand. (2017). National framework and evidential requirements: New Zealand Nursing Professional Development and Recognition Programmes for Registered and Enrolled Nurses. Wellington, New Zealand: Author. Retrieved from https://www.nzno.org.nz/support/professional_development

Nursing Council of New Zealand. (2016). Approved professional development and recognition programmes. Wellington, New Zealand: Author. Retrieved from https://www.nursingcouncil.org.nz/Public/Nursing/PDRPs/NCNZ/nursing-section/ PDRPs.aspx

Peach, J. (2013). First PDRP fast-tracked in response to decade of discontent. Nursing Review, 13(6), 16-17.

Robson, C., \& McCartan, K. (2016). Real world research: A resource for users of social research in methods in applied settings. Chichester: John Wiley.

Teddlie, C., \& Tashakkori, A. (2009). Foundations of mixed methods research: Integrating quantitative and qualitative approaches in the social and behavioural sciences. Thousand Oaks, CA: Sage. 